\title{
ACE2 \& TMPRSS2 Expressions in Head \& Neck Tissues: A Systematic Review
}

\author{
Jerome R. Lechien ${ }^{1,2,3,4}$ - Thomas Radulesco ${ }^{1,5} \cdot$ Christian Calvo-Henriquez $^{1,6} \cdot$ Carlos M. Chiesa-Estomba $^{1,7}$. \\ Stéphane Hans $\mathrm{s}^{1,3}$. Maria R. Barillari ${ }^{1,8}$. Giovanni Cammaroto ${ }^{1,9}$. Géraldine Descamps ${ }^{1,2}$. Julien Hsieh ${ }^{1,10}$. \\ Luigi Vaira $^{1,11}$. Giacomo De Riu ${ }^{1,11}$. Leigh Sowerby ${ }^{1,12} \cdot$ Isabelle Gengler $^{1,13}$. Justin Michel ${ }^{1,5}$. Sven Saussez ${ }^{1,2,4}$
}

Received: 17 July 2020 / Accepted: 13 August 2020 / Published online: 20 August 2020

(c) Springer Science+Business Media, LLC, part of Springer Nature 2020

\begin{abstract}
To review the data regarding the expression of angiotensin converting enzyme-2 (ACE2) and transmembrane protease serine-2 (TMPRSS2) in head and neck tissue. Scopus, Cochrane Library, Medrxiv, Google Scholar and PubMED/MEDLINE were searched by four independent investigators for studies investigating ACE2 or TMPRSS2 expressions in head and neck tissues. The following outcomes were considered: sample origin (animal versus human); detection method; anatomical location and cell types. PRISMA checklist and modified population, intervention, comparison, outcome, timing and setting (PICOTS) framework were used to perform the review. Of the 24 identified studies, 17 met our inclusion criteria. Thirteen studies were conducted during the severe acute respiratory syndrome coronavirus-2 (SARS-CoV-2) pandemic. ACE2 and TMPRSS2 were expressed in oral, pharyngeal, sinusonasal human mucosa. The following cell types expressed ACE2: basal, apical, goblet, minor salivary, and endothelial cells. TMPRSS2 was found in goblet and apical respiratory cells. ACE2 and TMPRSS2 were found in the olfactory region, especially in sustentacular non-neural and neural stem cells. Animal studies suggested that ACE2 expression may vary regarding age. There was an important heterogeneity between studies in the methods used to detect ACE2 and TMPRSS2, leading to a potential identification bias. The SARS-CoV-2 receptors, ACE2 and TMPRSS2, are both expressed in many head and neck tissues, enabling the viral entry into the host organism.
\end{abstract}

Keywords ACE2 $\cdot$ TMPRSS2 $\cdot$ SARS-CoV-2 $\cdot$ COVID $\cdot$ Coronavirus $\cdot$ Head Neck

\section{Introduction}

The renin angiotensin aldosterone system is one of the most important systems regulating the homeostasis of cardiovascular and pulmonary function; this involves many molecules including angiotensin converting enzyme-2 (ACE2) [1]. ACE2 is also known to be the functional receptor of some coronavirus species as initially discovered in 2003 during the severe acute respiratory syndrome coronavirus (SARS-CoV) epidemic [2]. The current pandemic of coronavirus disease

Jerome R. Lechien and Thomas Radulesco have contributed equally to the paper and are joint as co-first authors.

Justin Michel and Sven Saussez equally contributed to the paper and are co-senior authors.

Jerome R. Lechien

jerome.lechien@umons.ac.be

Extended author information available on the last page of the article
2019 (COVID-19) has brought to light the importance of ACE2 regarding development of infection, viral spread and the development of the clinical COVID-19 [3]. At the same time, another SARS-CoV-2 receptor has been identified: the transmembrane protease serine-2 (TMPRSS2) [4].

ACE2 and TMPRSS2 tissue expressions are particularly important to identify viral entry pathways and to better understand the organ-related clinical presentation of the disease $[3,4]$. Further evaluation of ACE2 and TMPRSS2 expression in ear, nose and throat mucosa is warranted to shed light on the pathophysiology of disease in the head and neck [5-7].

The aim of this systematic review is to summarize the current data about the expression of ACE2 and TMPRSS2 in head \& neck tissue. 


\section{Methods}

The review was conducted regarding the Preferred Reporting Items for a Systematic Review and Meta-analysis (PRISMA) checklist [8]. A modified population, intervention, comparison, outcome, timing and setting (PICOTS) framework was used to structure the review process [9]. For this review, the PICOTS structure was kept but adapted to experimental/basic research studies on human and animal tissues.

\section{Studies}

Animal and human experimental published studies in English-language peer-reviewed journals were considered. Preprint studies were also considered in light of the current pandemic and the significant wealth of knowledge derived over the last few months. All studies where investigators assessed ACE2 or TMPRSS2 expressions in head $\&$ neck tissues through immunochemistry (IHC), in situ hybridization, Western Blot, RNA sequencing (RNA-seq), or reverse transcription polymerase chain reaction (RTPCR) were evaluated.

\section{Participants and Inclusion Criteria}

The papers had to include either human or animal subjects. The authors extracted substantial information about the sample characteristics (including species involved) and ACE2 and TMPRSS2 identification method.

\section{Outcomes}

The primary outcome studied was tissue expression of ACE2 and TMPRSS2. The anatomical location; the types of cells that expressed both receptors were recorded. Particular attention was paid to the method used to detect ACE2-TMPRSS2 in tissues. Additional useful information, such as viral impact on the functioning of the tissue/ cell that expressed the receptor or inter-individual differences, were also collected.

\section{Intervention and Comparison}

Because the aim of the study was to investigate the tissue ACE2 and TMPRSS2 expression, we did not consider potential intervention on patient or animal models.

\section{Timing and Setting}

We included the studies where the receptor analysis was made on normal subjects and/or infected patients.

\section{Search Strategy}

The PubMed/MEDLINE, Google Scholar, Medrxiv, Scopus and Cochrane search was conducted by 5 independent authors (JRL, TR, CCH, GD, CMCE) to identify papers published between January 1990 and April 2020. The authors screened publications with database abstracts and available full texts referring to the condition. The following keywords were used for the search strategy: 'ACE2'; 'TMPRSS2'; 'COVID-19'; 'COVID'; 'SARS'; 'coronav'; 'coronavirus'; 'salivary'; 'gland'; 'Receptor'; 'Head'; 'Neck'; 'Nasal'; 'ear, nose throat (ENT)'; 'Tissue' and 'Cell'. The authors investigated papers for number of samples/individuals, study type $\&$ design, inclusion criteria and ACE2/TMPRSS2 detection outcomes.

\section{Results}

The electronic search identified 24 papers, of which 17 met our inclusion criteria (Table 1) [10-26]. A total of 16 studies investigated the expression of ACE2 and TMPRSS2 in human head and neck tissues, while five papers focused on mouse and two on monkey samples respectively (Table 1). One study focused on ACE2 genetic analysis, without reporting site-specific anatomical expression [17]. The flow chart of the study process is available in Fig. 1. Five studies were preprint $[15,18-20,25]$.

\section{Tissue Expression in Human}

\section{ACE2 Expression}

ACE2 was assessed in 16 studies [11-26]. The expression of ACE2 was found in all mucosa of the respiratory upper tract, including trachea [12, 13, 20, 22, 25], sinus and nasal cavities $[11,16,20]$. Among the respiratory mucosa, ACE2 was expressed in several types of cells, including epithelial, goblet and endothelial cells [11, 12, 26]. One study reported that ACE2 was expressed on ciliated epithelial cells and not on non-ciliated (goblet) cells [20]. Butowt et al. compared the intensity of expression of ACE2 in the upper and lower respiratory tract [16]. They found that nasal epithelial cells had lower levels of ACE2 expression compared with epithelial cells of the lower respiratory tract [16]. Among the nasal region, two studies investigated the ACE2 expression in the 
Table 1 Studies reporting ACE2 or TMPRSS2 head and neck expression

\begin{tabular}{|c|c|c|c|c|c|}
\hline Authors & Design & Samples & Methods & ACE2 \& TMPRSS2 expression & Findings \\
\hline Vaarala & Mixed & Human & $\underline{\text { TMPRSS2 }}$ & $\underline{\text { Salivary glands }}$ & \multirow{2}{*}{$\begin{array}{l}\text { 1. TMPRSS } 2 \text { is expressed in human sali- } \\
\text { vary gland tissues }\end{array}$} \\
\hline $2001[10]$ & Study & Mouse & RNAseq & TMPRSS2 (human):+ & \\
\hline Hamming & Human & \multirow[t]{2}{*}{ Human } & $\underline{\mathrm{ACE} 2}$ & $\begin{array}{l}\text { Oral, Nasal, Nasopharyngeal Epithelium } \\
\text { \& endothelium }\end{array}$ & \multirow{2}{*}{$\begin{array}{l}\text { 1. ACE2 was found in endothelial (arter- } \\
\text { ies \& veins) and epithelial cells of } \\
\text { nasal, rhinopharyngeal and oral mucosa. } \\
\text { Precisely, the epithelium expression } \\
\text { concerned the basal layer cells }\end{array}$} \\
\hline $2004[11]$ & Study & & IHC & ACE2 human:+ (all mucosa) & \\
\hline Jia & Human & \multirow[t]{2}{*}{ Human } & $\underline{\mathrm{ACE} 2}$ & Tracheal Epithelium \& endothelium & \multirow{2}{*}{$\begin{array}{l}\text { 1. ACE2 was more expressed on the } \\
\text { apical than the basolateral surface of } \\
\text { polarized airway epithelia }\end{array}$} \\
\hline 2005 [12] & Study & & IHC \& biotinylation & ACE2 (human):+ & \\
\hline Liu & Experimenal & Monkey & $\underline{\mathrm{ACE} 2}$ & $\begin{array}{l}\text { Naso- Oro- Hypopharyngeal \& Tracheal } \\
\text { Epithelium }\end{array}$ & $\begin{array}{l}\text { 1. ACE2 is expressed in salivary gland } \\
\text { ducts of the pharyngeal glands }\end{array}$ \\
\hline \multirow[t]{2}{*}{$2011[13]$} & \multirow[t]{2}{*}{ Study } & & \multirow[t]{2}{*}{ IHC } & ACE2 Monkey:+ & $\begin{array}{l}\text { 2. ACE2 was expressed in epithelial cells } \\
\text { (lamina propria, respiratory tract) }\end{array}$ \\
\hline & & & & Virion in Saliva:+ & $\begin{array}{l}\text { 3. Virus was found in saliva of infected } \\
\text { monkeys }\end{array}$ \\
\hline \multirow{3}{*}{$\begin{array}{l}\text { Bilinska } \\
2020[14]\end{array}$} & \multirow{3}{*}{$\begin{array}{l}\text { Animal } \\
\text { Study }\end{array}$} & \multirow[t]{3}{*}{ Mouse } & ACE2 \& TMPRSS2 & Olfactory Epithelium & \multirow{2}{*}{$\begin{array}{l}\text { 1. ACE2 \& TMPRSS } 2 \text { are expressed } \\
\text { in sustentacular cells of the olfactory } \\
\text { epithelium but not/much less in most } \\
\text { olfactory receptor neurons }\end{array}$} \\
\hline & & & RNAseq, RT-PCR, & ACE2: sustentacular cells & \\
\hline & & & $\begin{array}{l}\text { In situ hybridization, } \\
\text { WB \& IHC }\end{array}$ & TMPRSS2: sustentacular cells & $\begin{array}{l}\text { 2. Expression of the entry proteins } \\
\text { increases in animals of old age }\end{array}$ \\
\hline & Mixed & Mouse & $\underline{\mathrm{ACE} 2} \&$ TMPRSS2 & Olfactory Epithelium & \multirow{2}{*}{$\begin{array}{l}\text { 1. In human, ACE2 \& TMPRSS2 were } \\
\text { not identified in purified olfactory } \\
\text { neurons }\end{array}$} \\
\hline \multirow{2}{*}{$2020[15]$} & \multirow[t]{2}{*}{ Study } & \multirow[t]{2}{*}{ Human } & \multirow[t]{2}{*}{ RNAseq } & $\begin{array}{l}\text { ACE2 \& TMPRSS2 Mouse: non-neu- } \\
\quad \text { ronal cells }\end{array}$ & \\
\hline & & & & $\begin{array}{l}\text { ACE2 \& TMPRSS } 2 \text { Human: glial and } \\
\text { neuronal stem cells }\end{array}$ & $\begin{array}{l}\text { 2. ACE2 was identified in glial cells \& } \\
\text { olfactory stem cells }\end{array}$ \\
\hline \multirow{5}{*}{$\begin{array}{l}\text { Butowt } \\
2020[16]\end{array}$} & \multirow{5}{*}{$\begin{array}{l}\text { Mixed } \\
\text { Study }\end{array}$} & & $\underline{\text { ACE2 \& TMPRSS2 }}$ & Olfactory Epithelium & \multirow{2}{*}{$\begin{array}{l}\text { 1. Nasal epithelial cells have lower levels } \\
\text { of ACE2 \& TMPRSS } 2 \text { compared with } \\
\text { epithelial cells of the lower respiratory } \\
\text { tract }\end{array}$} \\
\hline & & \multirow{4}{*}{ Human } & \multirow[t]{4}{*}{ RNAseq } & $\begin{array}{l}\text { ACE2 Mouse \& Human: non neuronal } \\
\text { cells }\end{array}$ & \\
\hline & & & & $\begin{array}{l}\text { TMPRSS2 Mouse \& Human: neuronal } \\
\text { \& non-neuronal cells }\end{array}$ & $\begin{array}{l}\text { 2. ACE2 has non-neuronal expression in } \\
\text { olfactory epithelium }\end{array}$ \\
\hline & & & & $\underline{\text { Respiratory Epithelium }}$ & \multirow{2}{*}{$\begin{array}{l}\text { 3. The expression of ACE } 2 \text { \& TMPRSS } 2 \\
\text { (mouse) were increased in elderly } \\
\text { mouse }\end{array}$} \\
\hline & & & & $\begin{array}{l}\text { ACE2 \& TMPRSS2 Human:+ (Lower } \\
\text { Airway > Nasal) }\end{array}$ & \\
\hline $\mathrm{Cao}$ & Human & Human & ACE2 gene & No localization provided & $\begin{array}{l}1.15 \text { unique expression quantitative trait } \\
\text { loci variants were found for ACE2 }\end{array}$ \\
\hline \multirow[t]{2}{*}{2020 [17] } & \multirow[t]{2}{*}{ Study } & & \multirow[t]{2}{*}{ Genetic Analyzis } & & $\begin{array}{l}\text { 2. The genotypes of ACE } 2 \text { gene polymor- } \\
\text { phism may be characterized by higher } \\
\text { expression levels of ACE2 in East Asian } \\
\text { population }\end{array}$ \\
\hline & & & & & $\begin{array}{l}\text { 3. There would be different susceptibility } \\
\text { or response to SARS-CoV2 in different } \\
\text { populations }\end{array}$ \\
\hline Chen & Human & Human & ACE2 & $\underline{\text { Salivary glands }}$ & \multirow{2}{*}{$\begin{array}{l}\text { 1. ACE2 is expressed in human granular } \\
\text { cells of salivary glands }\end{array}$} \\
\hline $2020[18]$ & Study & & RNAseq & ACE2 human:+ & \\
\hline Hikmet & Human & \multirow[t]{2}{*}{ Human } & $\underline{\mathrm{ACE} 2}$ & Nasopharyngeal Epithelium & \multirow{2}{*}{$\begin{array}{l}\text { 1. There was no ACE2 expression in } \\
\text { nasopharyngeal cells }\end{array}$} \\
\hline 2020 [19] & Study & & IHC & $\begin{array}{l}\text { ACE2 (human): no expression in naso- } \\
\text { pharynx }\end{array}$ & \\
\hline Lee & Human & Human & ACE2 & Tracheal, Nasal \& Sinusal Epithelium & $\begin{array}{l}\text { 1. ACE2 is expressed in ciliated epithelial } \\
\text { cells (cilia organelle) }\end{array}$ \\
\hline
\end{tabular}


Table 1 (continued)

\begin{tabular}{|c|c|c|c|c|c|}
\hline Authors & Design & Samples & Methods & ACE2 \& TMPRSS2 expression & Findings \\
\hline $2020[20]$ & Study & & $\mathrm{IHC}$ & ACE2 (human):+ & $\begin{array}{l}\text { 2.There was no ACE2 expression in the } \\
\text { non-ciliated goblet cells } \\
\text { 3. ACE2 expression is influenced by } \\
\text { patient demographics, clinical character- } \\
\text { istics, co-morbidities, or medication use. } \\
\text { The use of ACE inhibitor drugs did not } \\
\text { increase ACE2 protein expression }\end{array}$ \\
\hline $\mathrm{Li}$ & Human & Human & $\underline{\mathrm{ACE} 2}$ & Thyroid & 1. ACE2 is expressed by thyroid cells \\
\hline $\begin{array}{l}\text { Hikmet } \\
2020[19]\end{array}$ & $\begin{array}{l}\text { Human } \\
\text { Study }\end{array}$ & Human & $\frac{\underline{\mathrm{ACE} 2}}{\mathrm{IHC}}$ & $\begin{array}{l}\text { Nasopharyngeal Epithelium } \\
\text { ACE2 (human): no expression in naso- } \\
\text { pharynx }\end{array}$ & $\begin{array}{l}\text { 1. There was no ACE2 expression in } \\
\text { nasopharyngeal cells }\end{array}$ \\
\hline $2020[21]$ & Study & & RNAseq & ACE2 human:+ & \\
\hline Sungnak & Human & Human & ACE2 \& TMPRSS2 & Airway \& Nasal epithelium & $\begin{array}{l}\text { 1. ACE2 was expressed in airway epithe- } \\
\text { lial cells }\end{array}$ \\
\hline $2020[22]$ & Study & & RNAseq & $\begin{array}{l}\text { ACE2 human:+ } \\
\text { TMPRSS2 (human): subset of ACE2 } \\
\text { cells }\end{array}$ & $\begin{array}{l}\text { 2. ACE2 is more expressed in nasal } \\
\text { epithelial cells compared with other } \\
\text { respiratory cells (goblet \& ciliated cells) } \\
\text { 3. TMPRSS } 2 \text { is only expressed in a subset } \\
\text { of ACE } 2 \text { + cells }\end{array}$ \\
\hline $\mathrm{Xu}$ & Human & Human & $\underline{\text { ACE2 \& TMPRSS2 }}$ & Oral Epithelium & $\begin{array}{l}\text { 1. ACE2 is expressed in the oral cavity } \\
\text { epithelial cells }\end{array}$ \\
\hline $2020[23]$ & Study & & RNAseq & $\begin{array}{l}\text { ACE2 human:+ } \\
\text { Oral T cells, B cells \& fibroblasts } \\
\text { ACE2 human:+ }\end{array}$ & $\begin{array}{l}\text { 2. ACE } 2 \text { expression was higher in tongue } \\
\text { than buccal and gingival tissues }\end{array}$ \\
\hline $\begin{array}{l}\mathrm{Xu} \\
2020[24]\end{array}$ & $\begin{array}{l}\text { Human } \\
\text { Study }\end{array}$ & Human & $\begin{array}{l}\text { ACE2 } \\
\text { RNAseq }\end{array}$ & $\begin{array}{l}\text { Minor salivary glands } \\
\text { ACE2 human:+ }\end{array}$ & $\begin{array}{l}\text { 1. ACE2 is expressed in minor salivary } \\
\text { glands }\end{array}$ \\
\hline $\mathrm{Wu}$ & Human & Human & $\underline{\mathrm{ACE} 2}$ & Nasal \& Oral Epithelium & $\begin{array}{l}\text { 1. ACE is expressed in nasal epithelial } \\
\text { cells }\end{array}$ \\
\hline $2020[25]$ & Study & & RNAseq & ACE2 (human):+ & $\begin{array}{l}\text { 2. The was a higher virus concentration in } \\
\text { the nasal-swab comparing with throat- } \\
\text { swab, which is attributed to ACE2- } \\
\text { expression in nasal epithelial cells }\end{array}$ \\
\hline $\begin{array}{l}\text { Ziegler } \\
2020[26]\end{array}$ & $\begin{array}{l}\text { Mixed } \\
\text { Study }\end{array}$ & $\begin{array}{l}\text { Human } \\
\text { Monkey }\end{array}$ & $\begin{array}{l}\text { ACE2 \& TMPRSS2 } \\
\text { RNAseq }\end{array}$ & $\begin{array}{l}\text { Sinusal \& Nasal goblet epithelial cells } \\
\text { ACE2 \& TMPRSS2 Human:+ }\end{array}$ & $\begin{array}{l}\text { 1. ACE2 \& TMPRSS2 are co-expressed in } \\
\text { nasal goblet secretory cells }\end{array}$ \\
\hline
\end{tabular}

ACE2 Angiotensin Converting Enzyme-2, IHC Immunohistochemistry, RT-PCR reverse transcription polymerase chain reaction, SARS-CoV-2 severe acute respiratory syndrome coronavirus-2, TMPRSS2 transmembrane protease serine-2, WB Western Blotting

mucosa of the olfactory region, including olfactory bulb [15, 16]. The ACE2 receptor was identified in sustentacular/nonneuronal cells of the olfactory tissues. Moreover, ACE2 was found in a low proportion of neuronal stem cells in the olfactory bulb $[15,16]$. The expression of ACE2 in olfactory neurons (non-stem cells) remains uncertain because Butowt et al. and Brann et al. observed that ACE2 has only nonneuronal expression pattern in olfactory epithelium $[15,16]$.

Five studies investigated ACE2 expression in oral and pharyngeal regions, including oral, and hypo- oro- and nasopharyngeal spaces $[11,19,23-25]$. The study that explored ACE2 expression in human nasopharynx [19], did not exhibit significant ACE2 immunostaining in nasopharyngeal cells [19]. ACE2 receptor was identified in oral endothelial [11], epithelial [11, 23, 25], and salivary [24] cells. $\mathrm{Xu}$ et al. found that ACE2 was also expressed in $\mathrm{T}$ and $\mathrm{B}$ cells as well as fibroblasts of the oral cavity [23]. Moreover, ACE2 was expressed in major salivary gland tissues [18] and thyroid tissue [21]. In many publications, authors reported the type of cells (goblet versus epithelial versus stem cells) that expressed ACE2 or TMPRSS2 (Table 2). Interestingly, $\mathrm{Xu}$ et al. almost as much ACE- 2 expression in the thyroid as in the lungs [23].

The genetic analysis of $\mathrm{Cao}$ et al. reported that there are 15 unique expression quantitative trait loci variants in the East Asian population, supporting a gene polymorphism and tissue-related differences between individuals [17]. 
Fig. 1 Flow chart. ACE2 Angiotensin Converting Enzyme-2, TMPRSS2 transmembrane protease serine- 2

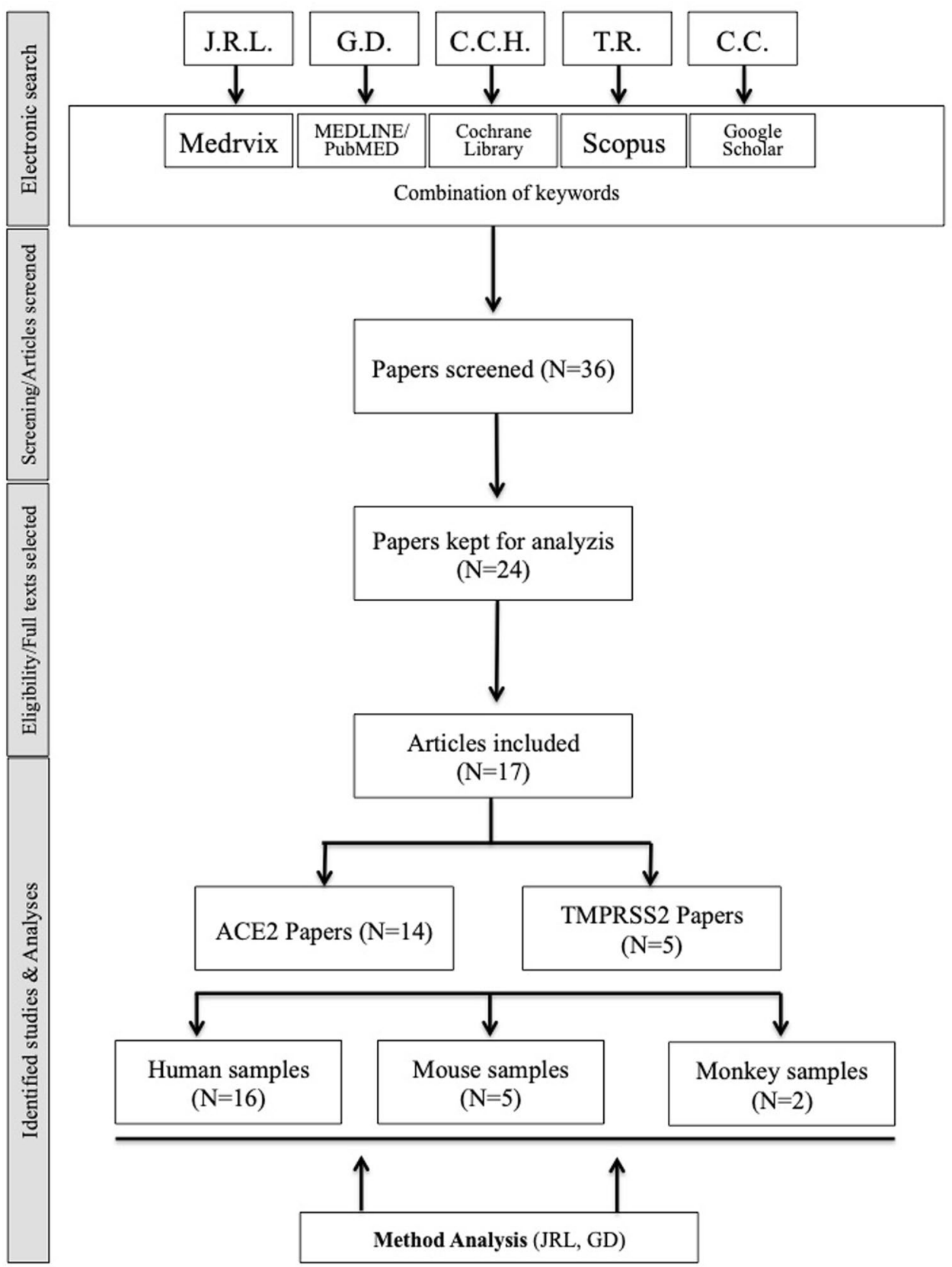

\section{TMPRSS2 Expression}

TMPRSS2 expression was investigated in 5 studies [10, $15,16,22,26]$. Similarly to ACE2, TMPRSS2 was identified in nasal $[16,22,26]$ and respiratory mucosa cells [22], including both epithelial and goblet cells, with higher expression in lower airway compared with upper airway [22]. Moreover, TMPRSS2 receptor was identified in sustentacular and neuronal olfactory cells $[15,16]$ but not in olfactory neurons [15]. TMPRSS2 was also identified in salivary major gland tissue [10].

\section{ACE2 \& TMPRSS2 Tissue Expression in Mouse and Monkey}

Six studies used animal models to assess ACE2 or TMPRSS2 expressions in head and neck tissues [10, 13-16, 26]. The mouse studies of Butowt et al. and Bilinska et al. revealed that elderly mice had higher expression of both ACE2 and TMPRSS2 in nasal mucosa compared with younger mice $[14,15]$. In olfactory tissue, ACE2 was identified in sustentacular/non-neuronal and neural stem cells of mice [14-16]. Liu et al. analyzed ACE2 expression in monkeys [13], 
Table 2 Summary of Cell Expression of ACE2 and TMPRSS2

\begin{tabular}{|c|c|c|c|c|c|}
\hline Authors & Samples & Tissue & Cell types & ACE2 & TMPRSS2 \\
\hline Bilinska [14] & Mouse & Olfactory & Sustentatorial & + & + \\
\hline \multirow[t]{3}{*}{ Brann [15] } & \multirow[t]{3}{*}{ Human \& Mouse } & \multirow[t]{3}{*}{ Olfactory } & Sustentatorial & + & + \\
\hline & & & Neuronal & - & - \\
\hline & & & Stem Neuronal & + & + \\
\hline \multirow[t]{3}{*}{ Butowt [16] } & \multirow[t]{3}{*}{ Human \& Mouse } & Nasal & Epithelial & + & + \\
\hline & & \multirow[t]{2}{*}{ Olfactory } & Sustentatorial & + & - \\
\hline & & & Neuronal & - & - \\
\hline Chen [18] & Human & Major Salivary Gland & Granular & + & NA \\
\hline \multirow[t]{2}{*}{ Hamming [11] } & \multirow[t]{2}{*}{ Human } & \multirow[t]{2}{*}{ Oral, Nasal, Nasopharyngeal } & Basal layer & + & NA \\
\hline & & & Endothelial & + & NA \\
\hline Hikmet [19] & Human & Nasopharyngeal & Epithelial & - & NA \\
\hline \multirow[t]{2}{*}{ Jia [12] } & \multirow[t]{2}{*}{ Human } & & Apical Epithelial & + & NA \\
\hline & & & Endothelial & + & NA \\
\hline \multirow[t]{2}{*}{ Lee $[20]$} & \multirow[t]{2}{*}{ Human } & \multirow[t]{2}{*}{ Tracheal, Nasal, Sinusal } & Apical Epithelial & + & NA \\
\hline & & & Goblet & - & NA \\
\hline $\operatorname{Li}[21]$ & Human & Thyroid & Unspecified & + & NA \\
\hline \multirow[t]{2}{*}{ Liu [13] } & \multirow[t]{2}{*}{ Monkey } & Pharyngeal & Minor salivary ductal & + & NA \\
\hline & & Tracheal & Basal layer & + & NA \\
\hline \multirow[t]{2}{*}{ Sungnak [22] } & \multirow[t]{2}{*}{ Human } & \multirow[t]{2}{*}{ Tracheal \& Nasal } & Goblet & + & + \\
\hline & & & Apical Epithelial & + & + \\
\hline Vaarala [10] & Human \& Mouse & Major Salivary Gland & Unspecified & NA & + \\
\hline \multirow[t]{3}{*}{$\mathrm{Xu}[23]$} & \multirow[t]{3}{*}{ Human } & \multirow[t]{3}{*}{ Oral } & Apical Epithelial & + & NA \\
\hline & & & Fibroblast & + & NA \\
\hline & & & $\mathrm{T}$ - and B-cells & + & NA \\
\hline $\mathrm{Xu}[24]$ & Human & Minor Salivary Gland & Unspecified & + & NA \\
\hline \multirow[t]{2}{*}{$\mathrm{Wu}[25]$} & \multirow[t]{2}{*}{ Human } & Nasal & Unspecified & + & NA \\
\hline & & Oral & Basal layer & + & NA \\
\hline Ziegler [26] & $\begin{array}{l}\text { Human, Mouse \& } \\
\text { Monkey }\end{array}$ & Nasal \& Sinusal & Goblet & + & + \\
\hline
\end{tabular}

ACE2 Angiotensin Converting Enzyme-2, NA not available, TMPRSS2 transmembrane protease serine-2

reporting a higher ACE2 expression in tracheal, naso-, oroand hypopharyngeal tissues as well as in the salivary ducts of the pharyngeal gland, and, consequently, in saliva. In this study, the cell expression was mainly localized in the lamina propria. In the same vein, Vaarala et al. reported TMPRSS2 expression in mouse salivary tissues [10].

\section{Cell Detection Methods}

The following methods have been used for detecting ACE2 and TMPRSS2 in cells of human and animal tissue: RNAseq $(\mathrm{N}=11)$; IHC $(\mathrm{N}=6)$; RT-PCR $(\mathrm{N}=1)$; in situ hybridization (ISH) $(\mathrm{N}=1)$ and $\mathrm{WB}(\mathrm{N}=1)$. Different detection approaches were used in 2 studies $[12,14]$. One study reported specific genetic analysis [17]. There were significant differences between studies regarding methods used. While Ziegler et al. and Sungnak et al. detected ACE2 by RNAseq in goblet cells, Lee et al. did not find any immunohistochemical labeling
[20, 22, 26]. However, the results reported in sustentacular cells agree in the same direction whatever the technique used, whether by RNAseq or by ISH and immunocytochemistry [14-16]. The discrepancies are rather observed between studies having performed immunohistochemistry. Indeed, using two different antibodies, Hikmet did not find ACE2 expression in nasopharynx epithelium whereas others demonstrated the staining of the apical surface of epithelia and ciliated epithelial cells [12, 19, 20]. Interestingly, all the studies which carried out RNAseq found an expression of ACE2 or TMPRSS2 at the epithelial level which implies that the technique used could generate biases between the studies [10, 18-20, 22-25]. 


\section{Discussion}

The presentation of COVID-19 infection may be in several clinical forms ranging from anosmia in isolation to severe multiple organ failure and death. The mechanisms underlying the COVID-19 polymorphism are still unknown. To infect tissues, SARS-CoV2 needs to entry into the cells, which is allowed through ACE2 and TMPRSS2 receptors [4]. The identification of virus receptor expression in the tissues makes particularly sense to better understand the clinical expression of the disease. This systematic review sheds light on many points.

First, ACE2 and TMPRSS2 receptors are expressed in epithelial and non-epithelial cells throughout the head and neck. The head and neck expression may support the otolaryngological clinical picture of the disease, which was recently found in European and North American COVID19 patients $[6,7,27,28]$. By entering the body via the epithelial cells of the upper aerodigestive tract mucosa, the SARS-CoV-2 virus leads to an inflammatory reaction and the development of otolaryngological symptoms. Nasal entrance of the virus through high ACE2 expression was supported in the study of $\mathrm{Wu}$ et al. who found a higher virus concentration in nasal swabs compared with throat swabs [25].
The olfactory cleft is a nasal region that has drawn the attention of many researchers over the past few weeks. Indeed, recent data supported that more than $70 \%$ of COVID-19 patients developed subjective olfactory dysfunction, especially when patients suffered from mildto-moderate forms of the disease [5, 7, 28, 29]. Because ACE2 and TMPRSS2 are both expressed in the nasal mucosa of the olfactory cleft, entrance into the olfactory bulb seems plausible. Once in the bulb, according to some human studies $[15,16]$, the virus could infect cells that express ACE2 or TMPRSS2, namely glial and neuronal stem cells (Fig. 2).

Integrating the molecular, clinical and radiological characteristics of SARS-COV-2 olfactory loss may shed light about its pathophysiological process. Taking into account that the loss is often temporary, SARS-COV-2 may primarily infect the sustentacular cells supporting the olfactory sensory neurons. This infection may cause rapid disruption of the olfactory epithelium structure and function with a possible inflammatory response inducing sudden onset smell loss. This inflammation is observed in a minority of patient with congested olfactory cleft who underwent CT scan [5, 7, 28, 30-32].

ACE2 and TMPRSS2 are also found in horizontal basal olfactory stem cells located in the basal layer. They are less exposed to the external environment, thus less likely to be infected in first line; the loss would have been more

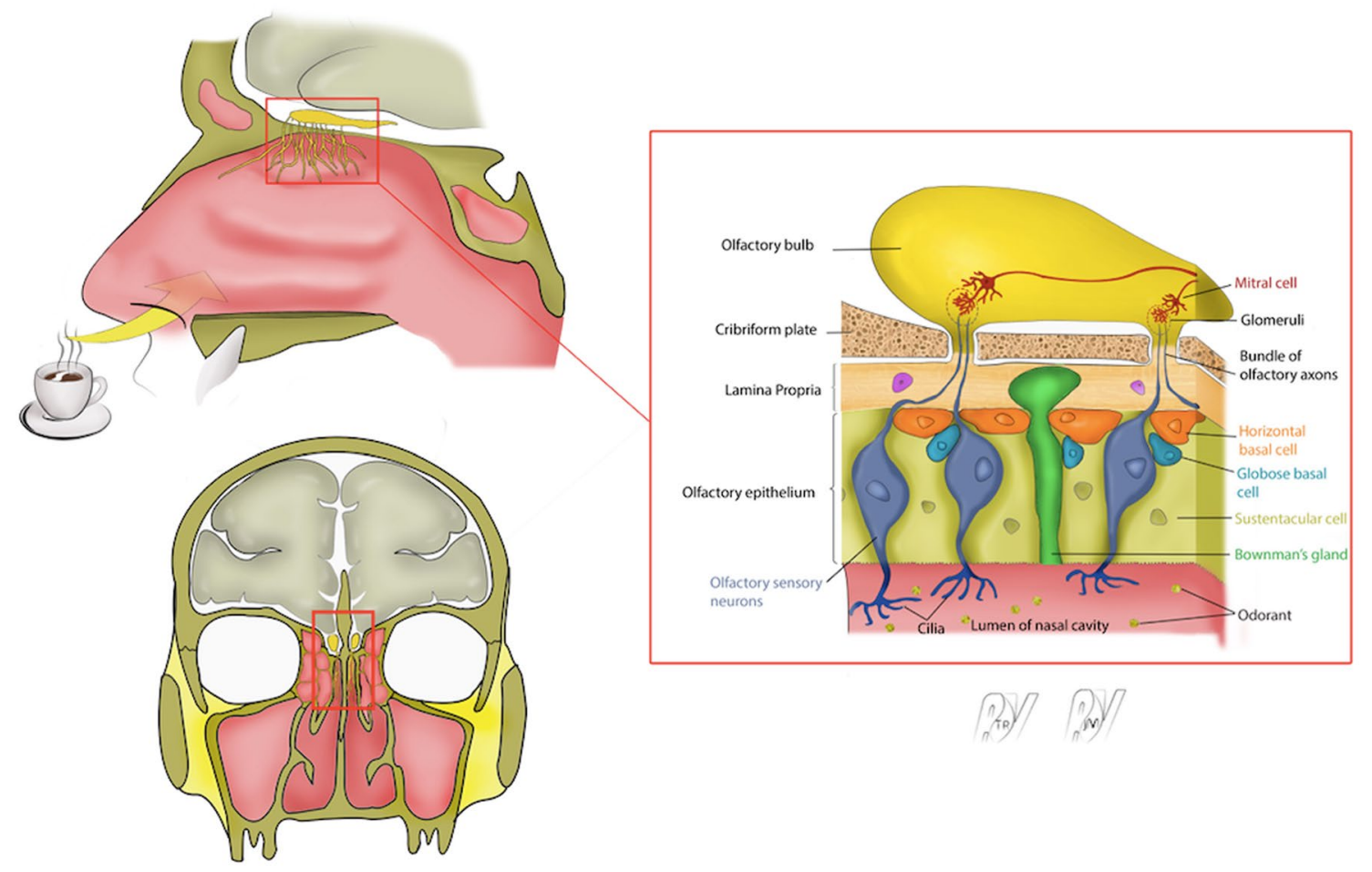

Fig. 2 Epithelium of Olfactory Cleft. The figure summarizes the olfactory cleft epithelium 
progressive. However, once infected, they might slow down recovery time because horizontal basal cells give rise to many cell type in the olfactory epithelium. They may also contribute to virus spread to the olfactory bulb vascular pericytes. Magnetic resonance imaging (MRI) studies of the olfactory bulb [33,34], in which ACE2 are only expressed in vascular pericytes but not in neurons, may show inflammatory signs suggesting that the infection process can extend more centrally and promote inflammatory response [35]. Inflammatory causes are often quickly reversible for example after a one-week trial of high dose of corticosteroids or simply days after the resolution of the viral infection suggesting that the olfactory neurons and bulbs are still somewhat intact. This seems to be the case for a majority of patients. In contrast, with more sustained destruction of neuronal olfactory structures, the recovery time is much longer and may take $2-3$ years, given the slow neuroregeneration process $[36,37]$.

In this systematic review, we found that three studies reported high ACE2 expression in major or minor salivary gland human tissues [10, 18, 24]. These data corroborate the literature findings that reported a salivary pattern of SARS-CoV-2 and related parotitis [38, 39]. Moreover, the virus spread into the salivary gland tissues allows us a better understanding the mechanisms underlying salivary transmission. Interestingly, in 2011, Liu et al. observed that monkeys infected by SARS-CoV had a salivary viral spread, which was associated with a salivary virion excretion [13]. These data support the need to conduct future studies investigating the presence of SARS-CoV-2 in the saliva of infected human and to corroborate the saliva findings with the ACE2 salivary gland expression.

The head and neck expression of ACE2 and TMPRSS2 and the related otolaryngological symptom pattern seems obvious but could vary across individuals and populations. In support of this, Lee et al. observed that ACE2 expression is influenced by patient demographics, clinical characteristics, co-morbidities and medication [20]. As reported in the genetic analysis of Cao et al., there would be different susceptibilities or responses to SARS-CoV2 in different populations [17]. The polymorphism of ACE2 and TMPRSS2 expression could explain the clinical differences between individuals. Indeed, many physicians reported in clinical and epidemiological studies different clinical presentation of the disease [28, 30], which could be associated with virus mutations $[40,41]$. The virus mutations and the related impact on receptor binding and infectivity is another point that has to be considered in future studies. Otherwise, according to the Bgee database (https://bgee.org/), expression of ACE2 and TMPRSS2 evaluated in murine models may increase with age. These findings have to be confirmed in humans, but could explain more severe clinical pictures in the elderly.
The present study has several limitations. First, the heterogeneity between studies about the detection method may lead to detection bias as some approaches are more sensitive than others. Some studies interrogate gene expression at mRNA level and others at protein levels, both types of analysis having their advantages and limitations. Compared to transcriptomic analyzes, immunohistochemistry brings additional important spatial information in tissue samples but recently Sorokin et al. demonstrated high and statistically significant correlations between the RNA sequencing and immunohistochemical measurements [42]. Interestingly, they highlighted the complementarity of both techniques for measuring cancer biomarkers in FFPE samples. However, differences observed across IHC studies suggest the involvement of many parameters. The antibody specificity is a big challenge to ensure reproducibility of antibody-based studies and given the high homology between ACE1 and ACE2, cautions must be taken regarding antibody selection. Besides, a report from the International Working Group for Antibody Validation (IWGAV) proposed five scientific approaches to validate antibody specificity [43], then such strategies must be considered in future investigations to confirm the published observations. In addition, it seems essential to enlarge and diversify patient cohorts and to combine transcriptomic and proteomic strategies as well as colocalize different markers of SARS-CoV-2, such as ACE2 and TMPRSS2, to provide an accurate representation of ACE2 expression through all head and neck areas of the whole population.

Second, the majority of studies that were conducted during the SARS-CoV-2 pandemic did not consider many demographic and clinical factors such as the age of patients from who the tissues were extracted or the use of ACE inhibitor medications among others. Third, some otolaryngological regions remain uninvestigated such as the vocal folds. The investigation of these remaining regions may shed further light on some recently reported unusual clinical phenomena such as severe dysphonia [44].

\section{Conclusion}

ACE2 and TMPRSS2 are both expressed in head and neck tissues, which may explain the otolaryngological clinical pattern of the disease and the entry of SARS-CoV-2 into the host organism. Future studies considering demographical and clinical characteristics of patients from who the tissues are extracted are needed to better understand the cell entry mechanisms of SARS-CoV-2.

Author contributions JR, TR, SS, JM: design, acquisition of data, data analysis \& interpretation, drafting, final approval, and accountability 
for the work; final approval of the version to be published; agreement to be accountable for all aspects of the work in ensuring that questions related to the accuracy or integrity of any part of the work are appropriately investigated and resolved. $\mathrm{CCH}, \mathrm{CMCE}, \mathrm{MRB}, \mathrm{IG}$ : design, data analysis \& interpretation, revising the manuscript for important intellectual content; final approval of the version to be published, final approval, and accountability for the work; final approval of the version to be published; agreement to be accountable for all aspects of the work in ensuring that questions related to the accuracy or integrity of any part of the work are appropriately investigated and resolved. LS, $\mathrm{SH}, \mathrm{GC}, \mathrm{GD}, \mathrm{JH}, \mathrm{LV}, \mathrm{GR}$ : design, acquisition of data, data analysis \& interpretation, drafting some parts of the manuscript; final approval of the version to be published, final approval, and accountability for the work; final approval of the version to be published; agreement to be accountable for all aspects of the work in ensuring that questions related to the accuracy or integrity of any part of the work are appropriately investigated and resolved.

\section{Compliance with Ethical Standards}

Conflict of interest The authors declare that they have no conflict of interest.

\section{References}

1. Crackower MA, Sarao R, Oudit GY, et al. Angiotensin-converting enzyme 2 is an essential regulator of heart function. Nature. 2002;417(6891):822-8.

2. Li W, Moore MJ, Vasilieva N, Sui J, Wong SK, Berne MA, Somasundaran M, Sullivan JL, Luzuriaga K, Greenough TC, Choe H, Farzan M. Angiotensin-converting enzyme 2 is a functional receptor for the SARS coronavirus. Nature. 2003;426(6965):450-4.

3. Wang Z, Xu X. scRNA-seq profiling of human testes reveals the presence of the ACE2 receptor, a target for SARS-CoV-2 infection in spermatogonia, leydig and sertoli cells. Cells. 2020;9(4):920. https://doi.org/10.3390/cells9040920.

4. Shang J, Wan Y, Luo C, Ye G, Geng Q, Auerbach A, Li F. Cell entry mechanisms of SARS-CoV-2. Proc Natl Acad Sci USA. 2020. https://doi.org/10.1073/pnas.2003138117.

5. Vaira LA, Hopkins C, Salzano G, et al. Olfactory and gustatory function impairment in COVID-19 patients: An Italian objective multicenter-study. Head Neck. https://doi.org/10.1002/hed.26269.

6. Lechien JR, Chiesa-Estomba CM, Place S, Van Laethem Y, Cabaraux P, Mat Q, Huet K, Plzak J, Horoi M, Hans S, Barillari MR, Cammaroto G, Fakhry N, Martiny D, Ayad T, Jouffe L, Hopkins C, Saussez S. COVID-19 task force of YO-IFOS. Clinical and epidemiological characteristics of 1420 European patients with mild-to-moderate Coronavirus Disease 2019. J Intern Med. 2020. https://doi.org/10.1111/joim.13089.

7. Lechien JR, Chiesa-Estomba CM, De Siati DR, et al. Olfactory and gustatory dysfunctions as a clinical presentation of mild-tomoderate forms of the coronavirus disease (COVID-19): a multicenter European study. Eur Arch Otorhinolaryngol. 2020. https:// doi.org/10.1007/s00405-020-05965-1.

8. McInnes MDF, Moher D, Thombs BD, et al. Preferred reporting items for a systematic review and meta-analysis of diagnostic test accuracy studies: the PRISMA-DTA statement. JAMA. 2018;319(4):388-96. https://doi.org/10.1001/jama.2017.19163.

9. Thompson M, Tiwari A, Fu R, Moe E, Buckley DI. A Framework To Facilitate the Use of Systematic Reviews and Meta-Analyses in the Design of Primary Research Studies. Rockville: Agency for Healthcare Research and Quality (US); 2012.
10. Vaarala MH, Porvari KS, Kellokumpu S, Kyllönen AP, Vihko PT. Expression of transmembrane serine protease TMPRSS2 in mouse and human tissues. J Pathol. 2001;193(1):134-40. https ://doi.org/10.1002/1096-9896(2000)9999:9999.

11. Hamming I, Timens W, Bulthuis ML, Lely AT, Navis G, van Goor H. Tissue distribution of ACE2 protein, the functional receptor for SARS coronavirus. A first step in understanding SARS pathogenesis. J Pathol. 2004;203(2):631-7. https://doi. org/10.1002/path.1570.

12. Jia HP, Look DC, Shi L, et al. ACE2 receptor expression and severe acute respiratory syndrome coronavirus infection depend on differentiation of human airway epithelia. J Virol. 2005;79(23):14614-21. https://doi.org/10.1128/ JVI.79.23.14614-14621.2005.

13. Liu L, Wei Q, Alvarez X, et al. Epithelial cells lining salivary gland ducts are early target cells of severe acute respiratory syndrome coronavirus infection in the upper respiratory tracts of rhesus macaques. J Virol. 2011;85(8):4025-30. https://doi. org/10.1128/JVI.02292-10.

14. Bilinska K, Jakubowska P, Von Bartheld CS, Butowt R. Expression of the SARS-CoV-2 entry proteins, ACE2 and TMPRSS2, in Cells of the olfactory epithelium: identification of cell types and trends with age. ACS Chem Neurosci. 2020. https://doi. org/10.1021/acschemneuro.0c00210.

15. Brann DH, Tsukahara T, Weinreb $\mathrm{C}$ et al. Non-neuronal expression of SARS-CoV-2 entry genes in the olfactory system suggests mechanisms underlying COVID-19-associated anosmia. Preprint. https://doi.org/10.1101/2020.03.25.009084.

16. Butowt R, Bilinska K. SARS-CoV-2: olfaction, brain infection, and the urgent need for clinical samples allowing earlier virus detection. ACS Chem Neurosci. 2020;11(9):1200-3. https://doi. org/10.1021/acschemneuro.0c00172.

17. Cao Y, Li L, Feng Z, Wan S, Huang P, Sun X, Wen F, Huang $X$, Ning G, Wang W. Comparative genetic analysis of the novel Coronavirus (2019-nCoV/SARS-CoV-2) receptor ACE2 in different populations. Cell Discov. 2020;6:11. https://doi. org/10.1038/s41421-020-0147-1.

18. Chen R, Wang K, Yu J et al. The spatial and cell-type distribution of SARS-CoV-2 receptor ACE2 in human and mouse brain. Preprint. https://doi.org/10.1101/2020.04.07.030650.

19. Hikmet F, Méar L, Uhlén M, Lindskog C. The protein expression profile of ACE2 in human tissues. bioRxiv. 2020. https:// doi.org/10.1101/2020.03.31.016048.

20. Lee IT, Nakayama T, Wu CT, et al. Robust ACE2 protein expression localizes to the motile cilia of the respiratory tract epithelia and is not increased by ACE inhibitors or angiotensin receptor blockers. Preprint. https://doi.org/10.1101/2020.05.08.20092 866.

21. Li MY, Li L, Zhang Y, Wang XS. Expression of the SARS-CoV-2 cell receptor gene ACE2 in a wide variety of human tissues. Infect Dis Poverty. 2020;9(1):45. https://doi.org/10.1186/s40249-02000662-x.

22. Sungnak W, Huang N, Bécavin C, et al. SARS-CoV-2 entry factors are highly expressed in nasal epithelial cells together with innate immune genes. Nat Med. 2020;26(5):681-7. https://doi. org/10.1038/s41591-020-0868-6.

23. Xu H, Zhong L, Deng J, Peng J, Dan H, Zeng X, Li T, Chen Q. High expression of ACE2 receptor of 2019-nCoV on the epithelial cells of oral mucosa. Int J Oral Sci. 2020;12(1):8. https://doi. org/10.1038/s41368-020-0074-x.

24. Xu J, Li Y, Gan F, Du Y, Yao Y. Salivary glands: potential reservoirs for COVID-19 asymptomatic infection. J Dent Res. 2020. https://doi.org/10.1177/0022034520918518.

25. Wu C, Zheng S, Chen Y, Zheng M. Single-cell RNA expression profiling of ACE2, the putative receptor of Wuhan 2019-nCoV, in the nasal tissue. https://doi.org/10.1101/2020.02.11.20022228 
26. Ziegler CGK, Allon SJ, Nyquist SK, et al. SARS-CoV-2 receptor ACE2 is an interferon-stimulated gene in human airway epithelial cells and is detected in specific cell subsets across tissues. Cell. 2020;S0092-8674(20):30500-6. https://doi.org/10.1016/j. cell.2020.04.035.

27. Kaye R, Chang CWD, Kazahaya K, Brereton J, Denneny JC III. COVID-19 anosmia reporting tool: initial findings. Otolaryngol Head Neck Surg. 2020. https://doi.org/10.1177/019459982092299 2.

28. Lechien JR, Chiesa-Estomba CM, Hans S, Barillari MR, Jouffe L, Saussez S. Loss of smell and taste in 2013 European patients with mild to moderate COVID-19. Ann Intern Med. 2020. https ://doi.org/10.7326/M20-2428.

29. Vaira LA, Salzano G, Deiana G, De Riu G. Anosmia and ageusia: common findings in COVID-19 patients. Laryngoscope. 2020. https://doi.org/10.1002/lary.28692.

30. Spinato G, Fabbris C, Polesel J, Cazzador D, Borsetto D, Hopkins C, Boscolo-Rizzo P. Alterations in smell or taste in mildly symptomatic outpatients with SARS-CoV-2 infection. JAMA. 2020. https://doi.org/10.1001/jama.2020.6771.

31. Lechien JR, Michel J, Radulesco T, Chiesa-Estomba CM, Vaira LA, De Riu G, et al. Clinical and radiological evaluations of COVID-19 patients with anosmia: preliminary report. Laryngoscope. 2020. https://doi.org/10.1002/lary.28993.

32. Whitcroft KL, Hummel T. Olfactory dysfunction in covid-19: diagnosis and management. JAMA. 2020. https://doi.org/10.1001/ jama.2020.8391.

33. Laurendon T, Radulesco T, Mugnier J, Gérault M, Chagnaud C, El Ahmadi AA, Varoquaux A. Bilateral transient olfactory bulbs edema during COVID-19-related anosmia. Neurology. 2020. https ://doi.org/10.1212/WNL.0000000000009850.

34. Chetrit A, Lechien JR, Ammar A, Chekkoury-Idrissi Y, Distinguin L, Circiu M, et al. Magnetic resonance imaging of COVID19 anosmic patients reveals abnormalities of the olfactory bulb: preliminary prospective study. J Infect. 2020. https://doi. org/10.1016/j.jinf.2020.07.028.

35. Peterson J, Lin B, Barrios-Camacho CM, et al. Activating a reserve neural stem cell population in vitro enables engraftment and multipotency after transplantation. Stem Cell Rep. 2019;12(4):680-95. https://doi.org/10.1016/j.stemcr.2019.02.014.

36. Bogdanov V, Walliczek-Dworschak U, Whitcroft KL, Landis BN, Hummel T. Response to glucocorticosteroids predicts olfactory outcome after ESS in chronic rhinosinusitis. Laryngoscope. 2019. https://doi.org/10.1002/lary.28233.

37. Cavazzana A, Larsson M, Münch M, Hähner A, Hummel T. Postinfectious olfactory loss: a retrospective study on 791 patients. Laryngoscope. 2018;128(1):10-5. https://doi.org/10.1002/ lary.26606.

38. Lechien JR, Chetrit A, Chekkoury-Idrissi Y, Distinguin L, Circiu M, Saussez S, et al. Parotitis-like symptoms associated with COVID-19, France, March-April 2020. Emerg Infect Dis. 2020. https://doi.org/10.3201/eid2609.202059.

39. Capaccio P. A possible precocious clinical manifestation of SARS-CoV-2 infection? Otolaryngol Head Neck Surg. 2020. https ://doi.org/10.1177/0194599820926992.

40. Coppee F, Lechien JR, Decleves AE, Tafforeau L, Saussez S. SARS-CoV-2: virus mutations in specific European populations. New Micr New Infec. 2020. https://doi.org/10.1016/j. nmni.2020.100696.

41. Saha P, Banerjee AK, Tripathi PP, Srivastava AK, Ray U. A virus that has gone viral: amino acid mutation in S protein of Indian isolate of Coronavirus COVID-19 might impact receptor binding, and thus, infectivity. Biosci Rep. 2020. https://doi.org/10.1042/ BSR20201312.

42. Sorokin M, Ignatev K, Poddubskaya E, Vladimirova U, Gaifullin N, Lantsov D, Garazha A, Allina D, Suntsova M, Barbara V, Buzdin A. RNA sequencing in comparison to immunohistochemistry for measuring cancer biomarkers in breast cancer and lung cancer specimens. Biomedicines. 2020;8(5):114. https://doi.org/10.3390/ biomedicines8050114.

43. Uhlen M, Bandrowski A, Carr S, Edwards A, Ellenberg J, Lundberg E, et al. A proposal for validation of antibodies. Nat Methods. 2016;13:823-7.

44. Lechien JR, Chiesa-Estomba CM, Cabaraux P, Mat Q, Huet K, Harmegnies B, et al. Features of mild-to-moderate COVID-19 patients with dysphonia. J Voice. 2020; https://doi.org/10.1016/j. jvoice.2020.05.012.

Publisher's Note Springer Nature remains neutral with regard to jurisdictional claims in published maps and institutional affiliations.

\section{Affiliations}

\section{Jerome R. Lechien ${ }^{1,2,3,4}$ - Thomas Radulesco ${ }^{1,5} \cdot$ Christian Calvo-Henriquez $^{1,6} \cdot$ Carlos M. Chiesa-Estomba $^{1,7}$. Stéphane Hans $s^{1,3}$. Maria R. Barillari ${ }^{1,8}$. Giovanni Cammaroto ${ }^{1,9}$. Géraldine Descamps ${ }^{1,2}$. Julien Hsieh ${ }^{1,10}$. Luigi Vaira $^{1,11}$. Giacomo De Riu ${ }^{1,11}$. Leigh Sowerby ${ }^{1,12} \cdot$ Isabelle Gengler ${ }^{1,13}$. Justin Michel ${ }^{1,5}$. Sven Saussez ${ }^{1,2,4}$}

1 COVID-19 Task Force of the Young-Otolaryngologists of the International Federations of Oto-RhinoLaryngological Societies (YO-IFOS), Paris, France

2 Department of Human Anatomy and Experimental Oncology, Faculty of Medicine, UMONS Research Institute for Health Sciences and Technology, University of Mons (UMons), Mons, Belgium

3 Department of Otolaryngology-Head \& Neck Surgery, School of Medicine, Foch Hospital, UFR Simone Veil, Université Versailles Saint-Quentin-en-Yvelines (Paris Saclay University), Paris, France
4 Department of Otorhinolaryngology and Head and Neck Surgery, CHU de Bruxelles, CHU Saint-Pierre, School of Medicine, Université Libre de Bruxelles, Brussels, Belgium

5 Department of Oto-Rhino-Laryngology Head and Neck Surgery, La Conception University Hospital, Aix Marseille Univ, APHM, IUSTI, Marseille, France

6 Department of Otolaryngology-Hospital Complex of Santiago de Compostela, Santiago de Compostela, Spain

7 Department of Otorhinolaryngology-Head \& Neck Surgery, Hospital Universitario Donostia, San Sebastian, Spain 
8 Department of Mental and Physical Health and Preventive Medicine, University of L. Vanvitelli, Naples, Italy

9 Department of Otolaryngology-Head \& Neck Surgery, Morgagni Pierantoni Hospital, Forli, Italy

10 Rhinology-Olfactology Unit, Department of Otorhinolaryngology, Head and Neck Surgery, Geneva University Hospitals (HUG), Geneva, Switzerland
11 Maxillofacial Surgery Unit, University Hospital of Sassari, Sassari, Italy

12 Department of Otolaryngology-Head and Neck Surgery, University of Western Ontario, London, ON, Canada

13 Department of Otolaryngology-Head and Neck Surgery, University of Cincinnati Medical Center, Cincinnati, OH, USA 